J. Perinat. Med. $12(1984) 13$

\section{Circulating $\beta$-2-microglobulin levels during pregnancy and their possible relationship with feto-maternal histocompatibility}

\author{
P. Bischof, C. Gruffat, M. Jeannet*, D. Hoffmeyer**, W. L. Herrmann, F. Beguin, \\ P. C. Sizonenko
}
Division of Clinical Biology of Growth and Reproduction
Department of Obstetrics and Gynecology
and
* Transplantation Unit, Hopital Cantonal Universitaire de Geneve
** Diagnostic Division Pharmacia pdf Switzerland

\section{Introduction}

$\beta 2$ microglobulin $(\beta 2 \mathrm{~m})$ is a low molecular weight protein $(11800)$ detectable on the surface of nearly all cell types with the exception of erythrocytes and trophoblastic cells [2].

On the surface of the cells, $\beta 2 \mathrm{~m}$ is associated with proteins coded for by loci of the major histocompatibility complex. It has been demonstrated that $\beta 2 \mathrm{~m}$ is the light chain of some HLA antigens [5].

Tumor cells and lymphocytes were shown to be high $\beta 2 \mathrm{~m}$ producers invitro suggesting that they might represent the major sites of $\beta 2 \mathrm{~m}$ synthesis [4].

In vitro, phytohemagglutinin stimulated lymphocytes release of $\beta 2 \mathrm{~m}$ in the medium [7].

Because of its low molecular weight, $\beta 2 \mathrm{~m}$ is filtrated through the normal glomerulus and reabsorbed by tubular cells.

Hence increased serum $\beta 2 \mathrm{~m}$ levels reflect either an increased synthesis and/or a defect glomerular filtration [6].

To our knowledge, no decreased $\beta 2 \mathrm{~m}$ levels have been reported so far. During pregnancy, glomerular filtration rate [8] as well as plasma volume are increased. Since plasma $\beta 2 \mathrm{~m}$ levels are not decreased but rather increased it must be assumed that during pregnancy the production of $\beta 2 \mathrm{~m}$ is enhanced [3]. According to BEER et al. [1] the success of a pregnancy also depends on the degree of histocompatibility between spouses. Because of

\section{Curriculum vitae}

PAUL BISCHOF, PhD. born in Geneva in 1945, graduated from the Unilersity of Genel'a in 1974. After three years of research on progesterone and estradiol receptors (C.IBA-GEIGY Ltd.. Basle) he started a research on pregnancy. associated plasma protein-A at the University of Aberdeen (Scotland). Since 1979 he is working in the

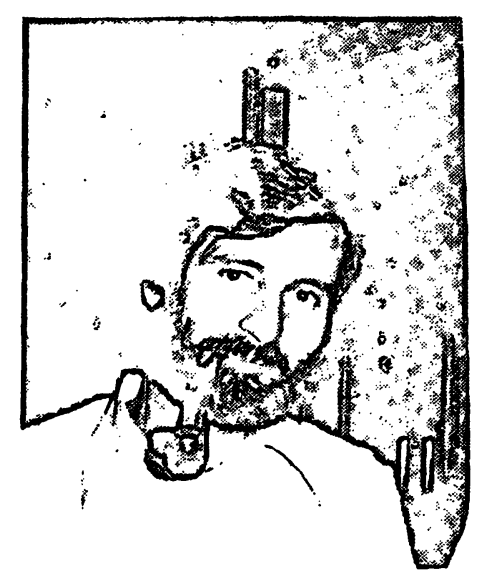
Department of Obstetrics and Gy'necology', University of Geneva. Current studies biological role of pregnancyassociated plasma protein-A and immunology' of preg. nancy'.

the close association between $\beta 2 \mathrm{~m}$ and HLA antigens it seemed interesting to measure plasma $\beta 2 \mathrm{~m}$ in normal and pathological pregnancies and to relate the values obtained to the degree of histoincompatibility between mother and fetus.

\section{Patients and methods}

Blood was withdrawn from pregnant patients. at different periods of gestation, into ethylenediamine tetraacetate $(2 \mathrm{mg} / \mathrm{ml}$ EDTA) containing tubes. Plasma was obtained by centrifugation and stored at $-20^{\circ} \mathrm{C}$ until measured.

$\beta 2 \mathrm{~m}$ was measured by radioimmunoassay using a commercially available kit (PHADEBAS $\beta 2 \mathrm{~m}$. Pharmacia Uppsala, Sweden). 
Patients included in this study were divided into 5 groups:

(A) Normal pregnant women (152 patients, 167 blood samples) who had delivered normal babies at term. (B) Pregnant patient with HLA compatibility: Mrs. C. (aged 29), one patient who was followed regularly during her 4 th and 5 th pregnancy (35 blood samples). She bears in common with her husband 4 out of 9 HLA antigens characterized (B44 (12), BW4, MT2, MT3). She had a history of 3 first trimester abortions. Her 4th pregnancy ended up by an intra-uterine death on the 27 th week of gestation. In her fifth pregnancy she had a ceserian section at week 30 for fetal distress and her child died 10 days later for unexplained reasons. (C) Twin pregnancies (20 women, 20 blood samples). Their placentae were examined macro- and microscopically and the morphology of the membranes recorded. (D) Toxemic pregnancies (35 patients, 35 blood samples). All patients had an increased blood pressure ( $>14 / 9$ on 2 occasions) associated either with edema and/or proteinuria. (E) Hydatidiform moles ( 7 patients, 7 blood samples obtained before curetage). All patients included in this group had a complete hydatidiform mole as diagnosed histologically).

Due to the skewed distribution of the data statistical evaluation was performed with the test of MANN-WHITTNEY.

\section{Results}

$\beta 2 \mathrm{~m}$ levels change during pregnancy, they decrease from the 8 th to the 14 th week, remain low up to the 18 th week and increase thereafter to reach a maximum at week 34 (Tab. I, Fig. 1).

$\beta 2 \mathrm{~m}$ concentrations during the 2 successive pregnancies of Mrs. C. were at or below the 10th percentile of the normal distribution (Fig. 1). Before her fifth pregnancy, her $\beta 2 \mathrm{~m}$ levels were within the normal range of non-pregnant subjects $(1.2 \mu \mathrm{g} / \mathrm{ml})$. The mean value between the $26 \mathrm{th}$ and the 28th week is significantly lower $(p<0.001)$ than the one of normal pregnancies (Fig. 2).

Patients with monozygotic twins (monochorionic membranes) have significantly lower $(p<0.001)$
Tab. I. Plasma $\beta 2$ microglobulin concentrations during pregnancy in $\mu \mathrm{g} / \mathrm{ml}$.

\begin{tabular}{|c|c|c|c|c|}
\hline Weeks & mean & $\therefore 1$ & S.D. & $\mathbf{n}$ \\
\hline $7-8$ & 1.45 & & 0.34 & 10 \\
\hline $9-10$ & 1.40 & & 0.55 & 10 \\
\hline $11-12$ & 1.22 & & 0.15 & 9 \\
\hline $13-14$ & $1.13 *$ & & 0.15 & 10 \\
\hline $15-16$ & 1.22 & & 0.27 & 10 \\
\hline $17-18$ & 1.31 & & 0.34 & 10 \\
\hline $19-20$ & 1.57 & & 0.32 & 10 \\
\hline $21-22$ & 1.49 & & 0.37 & 10 \\
\hline $23-24$ & 1.35 & & 0.29 & 9 \\
\hline $25-26$ & 1.44 & & 0.22 & 10 \\
\hline $27-18$ & 1.46 & & 0.35 & 10 \\
\hline $29-30$ & 1.74 & & 0.28 & 10 \\
\hline $31-32$ & $1.83 * *$ & & 0.37 & 10 \\
\hline $33-34$ & 1.75 & & 0.52 & 10 \\
\hline $35-36$ & 1.68 & & 0.31 & 9 \\
\hline $37-38$ & 1.69 & & 0.25 & 10 \\
\hline $39-40$ & 1.69 & & 0.54 & 10 \\
\hline
\end{tabular}

$\beta-2$-microglobuline

$(\mu \mathrm{g} / \mathrm{ml})$

$n=167$

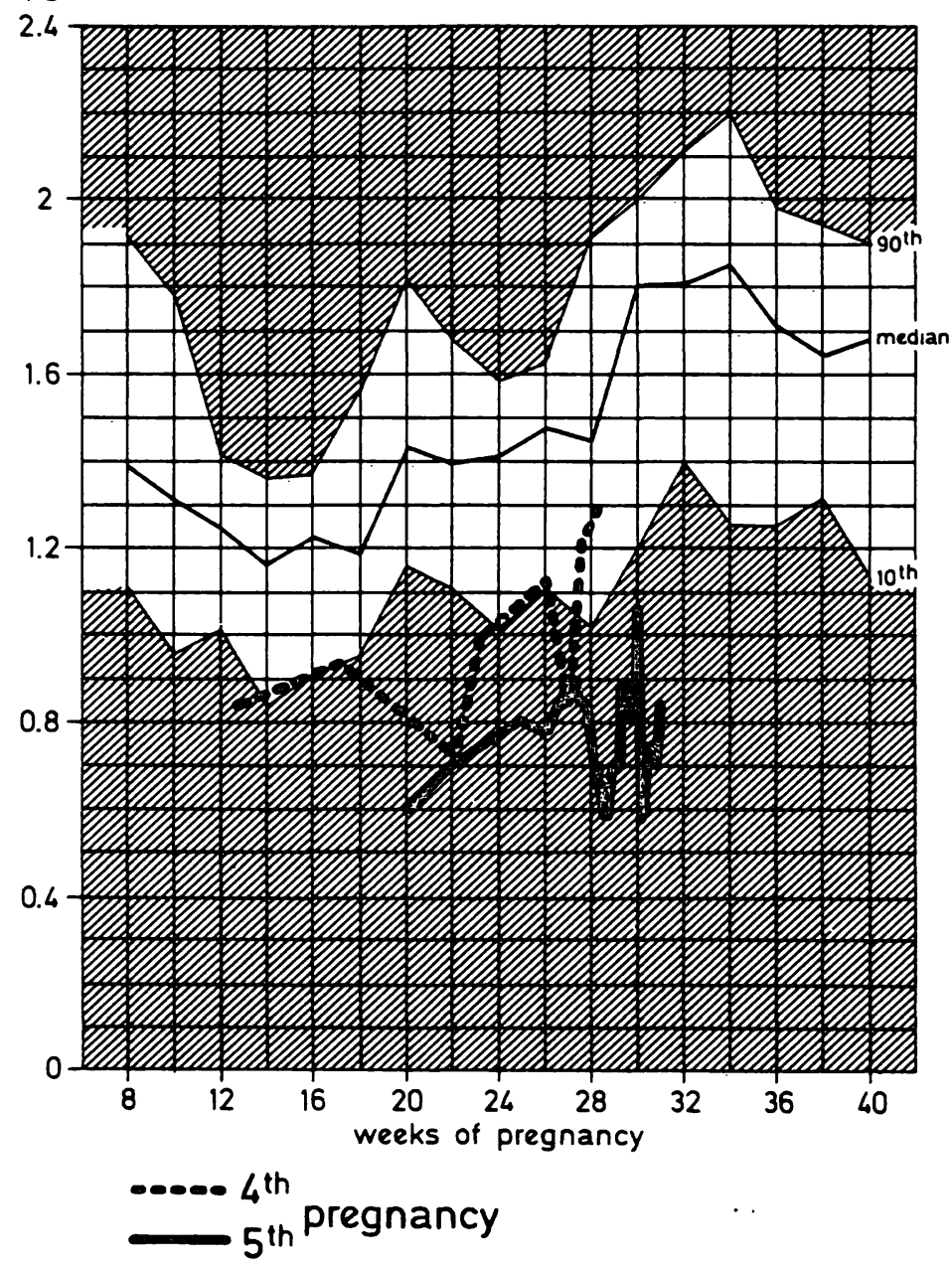

Fig. 1. Plasma $\beta 2 \mathrm{~m}$ levels in 2 successive pregnancies of a woman who shares HLA antigens with her husband. Comparison to plasma $\beta 2 \mathrm{~m}$ levels in normal pregnant women (values are groupe according to the period of amenorrhea as follow 7 th and 8 th week given as 8 th week etc. . .). 
2 Microglobulin and histocompatibility during pregnancy ( $\mu / \mathrm{mll})$ P2M

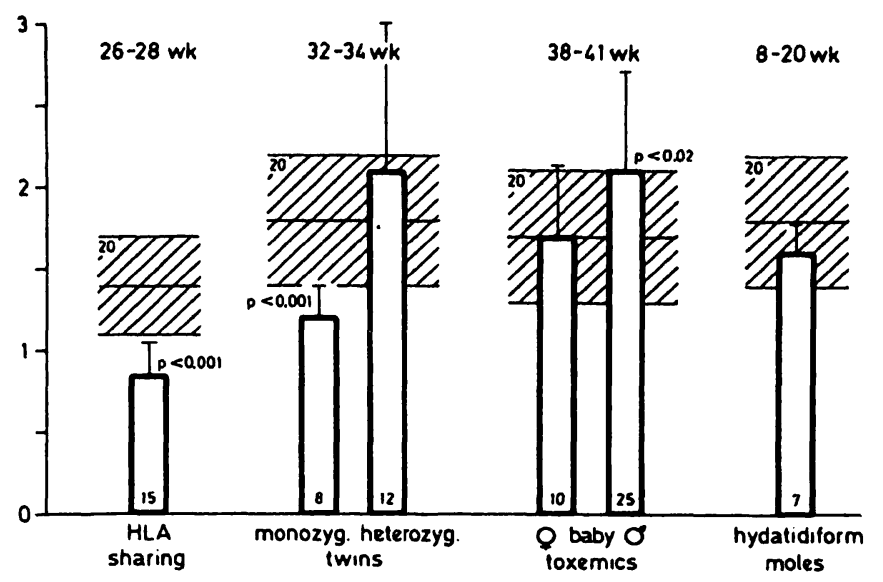

Fig. 2. Mean $\beta 2 \mathrm{~m}$ microglobulin concentration $( \pm \mathrm{SD})$ in normal (hached zone) and pathological pregnancies.

circulating $\beta 2 \mathrm{~m}$ levels than normal pregnant women or women bearing heterozygotic twins (Fig. 2). These latter patients had $\beta 2 \mathrm{~m}$ concentrations which were not statistically different from normal singleton pregnancies.

In patients suffering from toxemia, $\beta 2 \mathrm{~m}$ levels were not significantly different from normal pregnancies. However, patients bearing a male child had significantly higher $(p<0.02) \beta 2 \mathrm{~m}$ concentrations as compared to toxemic women having a female child (Fig. 2).

The 7 patients with hydatidiform moles had $\beta 2 \mathrm{~m}$ levels within the normal range (Fig. 2).

\section{Discussion}

The rate of glomerular filtration is often monitored by $\beta 2 \mathrm{~m}$ measurements: Decreased glomerular filtration rate being associated with increased $\beta 2 \mathrm{~m}$ levels. In the present study, none of the patients had high $\beta 2 \mathrm{~m}$ concentrations so that their renal function has to be considered as normal.

The observations reported here are consistant with the hypothesis that decreased $\beta 2 \mathrm{~m}$ concentrations seem to be correlated with an increased fetomaternal histocompatibility: In the case of Mrs. C. who bears common HLA antigens with her husband, $\beta 2 \mathrm{~m}$ levels are consistantly low during two successive pregnancies whereas they are normal in the non-pregnant state.

The same association between low levels of $\beta 2 \mathrm{~m}$ and increased histocompatibility is found in normal twin pregnancies where mothers bearing monozygotic twins have lower $\beta 2 \mathrm{~m}$ levels than mother having heterozygotic twins.

The presence of a $\mathrm{Y}$ chromosome in male fetuses is associated with an increased antigenic stimulation. TOIVANEN and HIRVONEN [9] found an increased incidence of pre-eclampsia in mothers bearing male fetuses. In the present study toxemic mothers with female fetuses have significantly lower $\beta 2 \mathrm{~m}$ levels than mothers bearing male fetuses and one might assume, as discussed by HIRVONEN and TOIVANEN [9], that with female fetuses the antigenic stimuli to the mother are less than with male fetuses. It is well known that the genotype of placental cells in hydatidiform moles is exclusively of paternal origin. So that the antigenic stimulation to the mother is considered to be important. In this study, $\beta 2 \mathrm{~m}$ levels of women with hydatidiform moles are within the normal range. It must be said however that the normal levels of $\beta 2 \mathrm{~m}$ have been collected from normal pregnancies in which antigenic stimulation is probably already maximal so that only hypostimulation is measurable.

Since lymphocytes could well be the major source of circulating $\beta 2 \mathrm{~m}$ one might assume that in women with a normal glomerular filtration rate plasma $\beta 2 \mathrm{~m}$ concentration probably reflects the secretory activity of lymphocytes.

Although the present data have been obtained from a limited number of patients particularly the HLA sharer ( 2 pregnancies from the same patient) we nevertheless think that they allow us to put forward a hypothesis which has to be verified namely that decreased $\beta 2 \mathrm{~m}$ levels during pregnancy might be associated with increased fetomaternal histocompatibility.

\section{Summary}

Plasma $\beta 2$ microglobulin $(\beta 2 \mathrm{~m})$ levels have been measured by radioimmunoassay in normal pregnant women, in two successive pregnancies of a woman who shares HLA antigens with her husband, in normal twin pregnancies, in toxemic pregnancies and in hydatidiform moles.
During normal pregnancy, plasma $\beta 2 \mathrm{~m}$ levels decrease reaching a minimum at week 14 and increase thereafter to a maximum at week 34 .

In the two successive pregnancies of the one patient with HLA compatibility, $\beta 2 \mathrm{~m}$ concentrations were significantly 
lower than in normal pregnancies. Women with monozygotic twins had significantly less $\beta 2 \mathrm{~m}$ than women with heterozygotic twins. Toxemic patients bearing female fetuses had also statistically lower $\beta 2 \mathrm{~m}$ levels than toxemic women with male fetuses.

Patients suffering from hydatidiform moles had $\beta 2 \mathrm{~m}$ levels in the range of normal pregnant patients.
Since circulating $\beta 2 \mathrm{~m}$ is produced by lymphocytes one might assume that low $\beta 2 \mathrm{~m}$ levels reflect a reduced activity of lymphocytes. The results presented here allow to propose a hypothesis which will have to be verified that reduced $\beta 2 \mathrm{~m}$ levels are associated with an increased feto-maternal histocompatibility.

Keywords: Beta-2-microglobuline, histocompatibility, HLA-antigens, pregnancy.

\section{Zusammenfassung}

Zirkulierende $\beta_{\mathbf{2}}$-Mikroglobuline während der Schwangerschaft als möglicher Parameter der feto-maternalen Histokompatibilität

Mit einem Radioimmunoassay bestimmten wir die $\beta_{2}$ Mikroglobulinspiegel im Plasma folgender Patientinnen: Bei Frauen mit unkomplizierter Schwangerschaft, bei einer Frau mit 2 aufeinanderfolgenden Schwangerschaften und gleichem HLA-Typ wie ihr Mann, bei normalen Zwillingsschwangerschaften, bei Schwangerschaftstoxikosen sowie bei Frauen mit einer Blasenmole.

Während einer normalen Schwangerschaft zeigt der $\beta_{2}$ Mikroglobulinspiegel zunächst eine fallende Tendenz mit einem Minimum in der 14 . Woche und danach einen Anstieg mit einem Maximum in der 34. Woche.

Bei den beiden Schwangerschaften der Patientin mit HLAKompatibilität lagen die $\beta_{2}$-Mikroglobulinspiegel signifi- kant niedriger als in der Kontrollgruppe. Frauen mit eineiigen Zwillingen wiesen geringere $\beta_{2}$-Mikroglobulinspiegel auf als Patientinnen mit zweieiigen $Z$ willingen. Bei den toxämischen Patientinnen hatten diejenigen mit weiblichen Feten niedrigere Spiegel als diejenigen mit männlichen Feten.

Die Patientinnen mit Blasenmole hatten $\beta_{\mathbf{2}}$-Mikroglobulinspiegel im Bereich der Kontrollgruppe.

Unter der Vorstellung, daß die zirkulierenden $\beta_{2}$-Mikroglobuline von den Lymphozyten produziert werden, könnte man annehmen, daß niedrige $\beta_{2}$-Mikroglobulinspiegel Ausdruck einer herabgesetzten Lymphozytenaktivität sind. Unsere Ergebnisse lassen eine Arbeitshypothese $\mathrm{zu}$, die verifiziert werden muß: Niedrige $\beta_{2}$-Mikroglobulinspiegel sind mit einer gesteigerten fetomaternalen Histokompatibilität assoziiert.

Schlüsselwörter: $\beta_{2}$-Mikroglobuline, Histokompatibilität, HLA-Antigene, Schwangerschaft.

\section{Résumé}

$\beta 2$-microglobuline circulante pendant la grossesse et son histocompatibilité fœto-maternelle

Les taux plasmatiques de $\beta 2$-microglobuline $(\beta 2 \mathrm{~m})$ ont été mesurés par radioimmunoassay chez des femmes enceintes groupées comme suit: Grossesses normales, grossesses gémellaires, grossesses avec prééclampsie, grossesses molaires et au cours de deux grossesses successives chez une patiente ayant des antigènes HLA en commun avec son mari.

Lors des grossesses normales, les taux de $\beta 2 \mathrm{~m}$ décroissent pour atteindre un minimum vers la 14ème semaine et augmentent ensuite atteignant un maximum à la 34ème semaine de gestation.

$\mathrm{Au}$ cours des deux grossesses successives chez la patiente présentant une compatibilité HLA, les taux de $\beta 2 \mathrm{~m}$ étaient significativement plus bas qu'au cours de grossesses normales. Les patientes ayant de vrais jumeaux avaient des taux de $\beta 2 \mathrm{~m}$ significativement plus bas que celles portant des faux jumeaux. Chez les patientes atteintes de prééclampsie, celles portant un enfant femelle avaient des taux significativement plus bas que celles portant un enfant mâle.

Comme la $\beta 2 \mathrm{~m}$ circulante est produite essentiellement par les lymphocytes on peut penser que des taux abaissés de $\beta 2 \mathrm{~m}$ reflètent une hyporéactivité lymphocytaire. Les résultats présentés ici permettent de poser l'hypothèse que des taux abaissés de $\beta 2 \mathrm{~m}$ sont associés avec une augmentation de l'histocompatiblité fœto-maternelle.

Mots-clés: $\quad \beta 2$-microglobuline, histocompatibilité, antigènes HLA, grossesse.

Acknowledgements: The authors wish to thank Pharmacia for supplying the kits and Mrs. D. ROIRON for typing the manuscript.

\section{Bibliography}

[1] BEER, A. E., J. F. QUEBbEMAN, J. W. T. AYERS, R. HAINES: Major histocompatibility complex antigens, maternal and paternal immune response, and chronic habitual abortions in human. Amer. J. Obstet. Gynec. 141 (1981) 987
[2]FAULK, W. P., A. TEMPLE: Distribution of $\beta 2 \mathrm{~m}$ microglobulin and HLA in chorionic villi of human placentae. Nature (London) 262 (1976) 780

[3] KELLY, A. M., M. B. MC NAY, H. P. MC EWAN: Renal tubular function in normal pregnancy. Brit. $J$. Obstet. Gynaecol. 85 (1978) 190 
[4]NIlsSON, K., P.E. ERVIN, K. I. Welsh: Production of $\beta 2$-microglobulin by normal and malignant human cell lines and peripheral lymphocytes. Transplant. Rev. 21 (1974) 53

[5] PETERSON, P. A., L. RASK, J. B. LINDBLOM: Highly purified papain solubilized HLA antigens contain $\beta 2 \mathrm{~m}$ microglobulin, a free immunoglobulin domain. Proc. Natl. Acad. Sci. USA 69 (1972) 1697

[6] PLESNER, T.: Immunochemical studies of human $\beta 2 \mathrm{~m}$ microglobulin. Allergy 35 (1980) 627

[7] POULIK, M. D., A. D. BLOOM: $\beta 2 \mathrm{~m}$ microglobulin production and secretion by lymphocytes in culture. J. Immunol. 110 (1973) 1430

[8] SIMS, E. A. H., K. E. KRANTZ: Serial studies of renal function during pregnancy and the puerperium in normal women. J. Clin. Invest. 37 (1958) 1764
[9] TOIVANEN, P., T. HIRVONEN: Placental weight in human foeto-maternal incompatibility. Clin. Exp. Immunol. 7 (1970) 533

Received January 2, 1983. Revised July 18, 1983.

Accepted September 15, 1983.
Dr. P. Bischof Laboratoire d'hormonologie Maternité 1211 Geneva 4 
. 